\title{
Sydoxanthone $C$ and acremolin B produced by deep-sea-derived fungus Aspergillus sp. SCSIO Ind09F01
}

\author{
Yongqi Tian ${ }^{1,2,4}$, Xiaochu Qin ${ }^{3,4}$, Xiuping Lin ${ }^{1}$, Kumaravel Kaliyaperumal ${ }^{1}$, Xuefeng Zhou ${ }^{1}$, Juan Liu ${ }^{1}$, \\ Zhiran $\mathrm{Ju}^{1}$, Zhengchao $\mathrm{Tu}^{3}$ and Yonghong Liu ${ }^{1}$
}

A new xanthone named sydoxanthone $C$ (1) and a new alkaloid named acremolin B (2), together with 10 known compounds (3-12) were isolated from a deep-sea-derived fungus Aspergillus sp. SCSIO Ind09F01. The structures of compounds (1-12) were determined by the extensive 1D, 2D-NMR, High resolution mass spectra (HRESIMS) data. Compounds $7,8,11$ and 12 showed significant selective cytotoxicities against HeLa, DU145 and U937 cell lines. In addition, compounds 7,8 and 11 also exhibited COX-2 inhibitory activities with the prominent $\mathrm{IC}_{50}$ values of $2.4,7.1$ and $10.6 \mu \mathrm{M}$, respectively.

The Journal of Antibiotics (2015) 68, 703-706; doi:10.1038/ja.2015.55; published online 6 May 2015

\section{INTRODUCTION}

Marine-derived fungi tend to produce structurally unique and biologically active natural products, which were documented in recent years. Marine fungi, has provided more than 1500 new natural products from 2010 to 2014, with a diverse array of chemical moieties including polyketides, alkaloids, terpenoids, peptides, prenylated polyketides and lipids. ${ }^{1-4}$ Especially, fungi from the deep-sea sediment and its derived compounds grabbed the attention of pharmaceutical chemists much in terms of its potential bioactivity. The deep sea is emerging as a new and interesting source of such microbes; however, only a handful of reports have described new metabolites from fungi derived from this habitat. ${ }^{5}$ As a wide stretch of this particular research theme, our present work resulted in the isolation of two new compounds along with 10 known compounds from the deep-seaderived fungal strain Aspergillus sp. SCSIO Ind09F01 isolated from the deep-sea sediment sample of Indian Ocean. Our preliminary experiment demonstrated that crude extract of the culture of Aspergillus sp. SCSIO Ind09F01 showed toxicity toward the brine shrimp. Further solid-phase fermentation of Aspergillus sp. SCSIO Ind09F01 followed by its crude ethyl acetate (EtOAc) extract yielded two new compounds: sydoxanthone $\mathrm{C}$ (1) and acremolin B (2) together with 10 known compounds (3-12): sydoxanthone B (3), ${ }^{6}$ engyodontiumone B (4), ${ }^{7}$ sydowinin B (5), ${ }^{8}$ acremolin (6),${ }^{9}$ diorcinol $(7),{ }^{10}$ cordyol C (8), ${ }^{11}$ cordyol E (9), ${ }^{12}$ methyl 2-hydroxy-4-(3-hydroxyl-5-methylphenoxy)6-methylbenzoate(10), ${ }^{13}$ 3,7-dihydroxy-1,9-dimethyldibenzofuran $(\mathbf{1 1})^{14}$ and AGI-B4 (12) ${ }^{15}$ (Figure 1). The cytotoxicity and COX-2 inhibitory activities of these compounds were individually evaluated. Herein, we described the isolation, structure elucidation and bioactivities of these metabolites 1-12 from Aspergillus sp. SCSIO Ind09F01.

\section{RESULTS AND DISCUSSION}

Compound 1 was obtained as a yellow amorphous solid. The molecular formula of $\mathbf{1}$ was established as $\mathrm{C}_{17} \mathrm{H}_{14} \mathrm{O}_{7} \mathrm{~S}$ by High resolution mass spectra (HRESIMS) (363.0521 $\left.[\mathrm{M}+\mathrm{H}]^{+}\right)$, requiring 11 degrees of unsaturations. The ${ }^{13} \mathrm{C}$ NMR, DEPT and HMQC spectra revealed the presence of 17 carbons, including 2 methyls (1 oxygenated), 1 oxygenated methylene, 4 aromatic methines, 8 aromatic quaternary carbons of which 3 were oxygenated and 2 carbonyl carbons. In the ${ }^{1} \mathrm{H}$ NMR spectrum, the most salient signals were 2 methyls at $\delta_{\mathrm{H}} 2.80(3 \mathrm{H}, \mathrm{s}), 3.95(3 \mathrm{H}, \mathrm{s})$, a methylene at $\delta_{\mathrm{H}} 4.61$ $(2 \mathrm{H}, \mathrm{s})$, four aromatic methines at $\delta_{\mathrm{H}} 6.81(1 \mathrm{H}, \mathrm{s}), 7.05(1 \mathrm{H}, \mathrm{s}), 8.01$ $(1 \mathrm{H}, \mathrm{d}, J=8.5 \mathrm{~Hz}), 8.39(1 \mathrm{H}, \mathrm{d}, J=8.5 \mathrm{~Hz})$ (Table 1). Comparison of UV-vis and NMR data with those of sydoxanthone B $(3)^{6}$ revealed a high degree of similarity. The only difference was the substituent of $\mathrm{C}-2$, especially the chemical shift values of $\mathrm{H}_{3}-12$ and C-12. Meanwhile, the strong correlation from $\mathrm{H}_{3}-12\left(\delta_{\mathrm{H}} 2.80\right)$ to $\mathrm{C}-2\left(\delta_{\mathrm{C}} 138.9\right)$ requirements of HRESIMS spectrum suggested that a methyl sulfonyl group was connected to C-2. Therefore, the structure of compound 1 was determined as pictured (Figure 2) and named sydoxanthone $\mathrm{C}$.

${ }^{1}$ CAS Key Laboratory of Tropical Marine Bio-resources and Ecology/Guangdong Key Laboratory of Marine Materia Medica/RNAM Center for Marine Microbiology, South China Sea Institute of Oceanology, Chinese Academy of Sciences, Guangzhou, China; ${ }^{2}$ University of Chinese Academy of Sciences, Beijing, China and ${ }^{3}$ Laboratory of Molecular Engineering and Laboratory of Natural Product Synthesis, Guangzhou Institutes of Biomedicine and Health, Chinese Academy of Sciences, Guangzhou, China

${ }^{4}$ These two authors contributed equally to this work.

Correspondence: Professor Z Tu, Laboratory of Molecular Engineering and Laboratory of Natural Product Synthesis, Guangzhou Institutes of Biomedicine and Health, Chinese Academy of Sciences, Guangzhou 510530, China.

E-mail: (tu_zhengchao@gibh.ac.cn)

or Dr Y Liu, CAS Key Laboratory of Tropical Marine Bio-resources and Ecology/Guangdong Key Laboratory of Marine Materia Medica/RNAM Center for Marine Microbiology, South China Sea Ins titute of Oceanology, Chinese Academy of Sciences, No 164 West Xinggang Road, Guangzhou, 510301 Guangdong, China.

E-mail: (yonghongliu@scsio.ac.cn)

Received 9 February 2015; revised 16 March 2015; accepted 23 March 2015; published online 6 May 2015 
<smiles>[R]c1ccc2oc3cc(CO)cc(O)c3c(=O)c2c1C(=O)OC</smiles><smiles>[R][R]#P</smiles><smiles>[R]c1cc(C)cc(Oc2cc(C)cc(O)c2[R])c1</smiles>

$7 \mathrm{R}_{1}=\mathrm{H}, \mathrm{R}_{2}=\mathrm{OH}$

$8 \mathrm{R}_{1}=\mathrm{OH}, \mathrm{R}_{2}=\mathrm{OH}$

$5 \mathrm{R}=\mathrm{OH}$<smiles>Cc1cc(O)cc2oc3cc(O)cc(C)c3c12</smiles>

11<smiles>COC(=O)[C@H]1c2c(oc3cc(CO)cc(O)c3c2=O)C=C[C@@H]1O</smiles>

12

Figure 1 Structures of compounds 1-12.

Table $1{ }^{1} \mathrm{H}$ and ${ }^{13} \mathrm{C}$ NMR data for 1 and 3 (at 500 and $125 \mathrm{MHz}$, respectively in DMSO-d6, $\delta$ p.p.m., $J$ in $\mathrm{Hz}$ )

\begin{tabular}{|c|c|c|c|c|c|}
\hline \multirow[b]{2}{*}{ Position } & \multicolumn{3}{|c|}{1} & \multicolumn{2}{|r|}{3} \\
\hline & $\delta_{c}$ & $\delta_{H}$ & $H M B C(H-C)$ & $\delta_{c}$ & $\delta_{H}$ \\
\hline 1 & 129.6 & & & 132.3 & \\
\hline 2 & 138.9 & & & 131.2 & \\
\hline 3 & 130.3 & $8.39(\mathrm{~d}, 8.5,1 \mathrm{H})$ & C-1, 4a & 136.4 & $8.02(\mathrm{~d}, 8.5,1 \mathrm{H})$ \\
\hline 4 & 121.6 & $8.01(\mathrm{~d}, 8.5,1 \mathrm{H})$ & $\mathrm{C}-2,4 \mathrm{a}, 9 \mathrm{a}$ & 120.2 & $7.79(\mathrm{~d}, 8.5,1 \mathrm{H})$ \\
\hline $4 a$ & 157.1 & & & 155.4 & \\
\hline $4 b$ & 154.8 & & & 154.0 & \\
\hline 5 & 104.1 & $7.05(\mathrm{~s}, 1 \mathrm{H})$ & $\mathrm{C}-6,7,13$ & 104.1 & $7.03(\mathrm{~s}, 1 \mathrm{H})$ \\
\hline 6 & 155.3 & & & 154.6 & \\
\hline 7 & 108.1 & $6.81(\mathrm{~s}, 1 \mathrm{H})$ & $C-5,8,8 a, 13$ & 107.7 & $6.80(\mathrm{~s}, 1 \mathrm{H})$ \\
\hline 8 & 160.5 & & & 160.6 & \\
\hline $8 a$ & 107.2 & & & 107.1 & \\
\hline 9 & 179.6 & & & 179.8 & \\
\hline $9 a$ & 116.5 & & & 116.9 & \\
\hline 10 & 165.9 & & & 167.0 & \\
\hline 11 & 53.1 & $3.95(\mathrm{~s}, 3 \mathrm{H})$ & C-10 & 52.6 & $3.91(\mathrm{~s}, 3 \mathrm{H})$ \\
\hline 12 & 43.2 & $2.80(\mathrm{~s}, 3 \mathrm{H})$ & C-2 & 17 & $2.55(\mathrm{~s}, 3 \mathrm{H})$ \\
\hline 13 & 62.2 & $4.61(\mathrm{~s}, 2 \mathrm{H})$ & $C-4 b, 5,7$ & 62.3 & $4.61(\mathrm{~s}, 2 \mathrm{H})$ \\
\hline
\end{tabular}

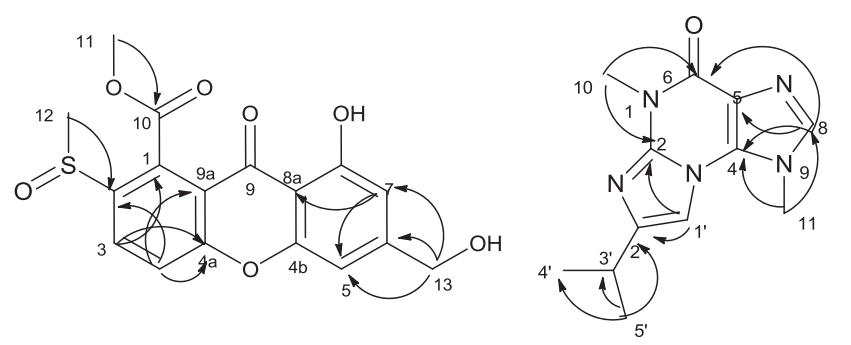

Figure 2 Key HMBC correlations of compounds 1 and 2.

Compound 2 was obtained as a white amorphous solid and has a molecular formula of $\mathrm{C}_{12} \mathrm{H}_{15} \mathrm{~N}_{5} \mathrm{O}$ as inferred from its HRESIMS $(\mathrm{m} / \mathrm{z}$ $\left.246.1346[\mathrm{M}+\mathrm{H}]^{+}\right)$requiring eight degrees of unsaturations. The ${ }^{1} \mathrm{H}$ NMR spectrum contained 15 proton signals: $4 \mathrm{sp}^{3}$ methyls at $\delta_{\mathrm{H}} 1.26$ $(6 \mathrm{H}, \mathrm{d}, J=7 \mathrm{~Hz}), 3.54(3 \mathrm{H}, \mathrm{s}), 4.02(3 \mathrm{H}, \mathrm{s}), 1 \mathrm{sp}^{3}$ aliphatic methine at $\delta_{\mathrm{H}}(1 \mathrm{H}, \mathrm{sept}, J=7 \mathrm{~Hz}), 2 \mathrm{sp}^{2}$ methines at $\delta_{\mathrm{H}} 7.58(1 \mathrm{H}, \mathrm{s})$ and 7.82
$(1 \mathrm{H}, \mathrm{s})$. The ${ }^{13} \mathrm{C}$ NMR spectrum showed 11 carbon signals (2 overlapping carbon signals). There are six olefinic carbons $\left(\delta_{\mathrm{C}} 103.7,118.1,133.7,138.6,142.9,148.4\right)$ besides four methyls $\left(\delta_{\mathrm{C}} 22.0,22.0,29.1,32.7\right)$, one methine $\left(\delta_{\mathrm{C}} 27.6\right)$ and one carbonyl carbon (155.1). Its NMR data are similar to that of acremolin $(6)^{9}$ with the only difference in the presence of one extra methyl $\left(\delta_{\mathrm{H}} 4.02\right.$ and $\left.\delta_{\mathrm{c}} 32.7\right)$, which suggests that compound 2 has the same skeleton as that of acremolin (6) with the only difference being the substitution at $\mathrm{N}-9$. This was proved by the HMBC spectrum showing correlation of $\mathrm{H}_{3}-11\left(\delta_{\mathrm{H}} 4.02\right)$ with $\mathrm{C}-8\left(\delta_{\mathrm{C}} 138.6\right) / \mathrm{C}-4\left(\delta_{\mathrm{C}} 133.7\right)$ (Table 2$)$. Therefore, the structure of 2 was determined and projected as shown (Figure 2) and named acremolin B.

Compounds 1-12 were assessed for its cytotoxicity efficacy against K562, MCF-7, HeLa, DU145, U937, H1975, SGC-7901, A549, MOLT-4 and HL60 cell lines by standard MTT screening method. Trichostatin A and taxol are used as a positive control. Finally, Compounds 7, 8, 11 and 12 showed moderate selective cytotoxicity against HeLa, DU145 and U937 cell lines (Table 3). All the compounds were subjected for COX-2 inhibitory activity, where compounds 7, 8 and $\mathbf{1 1}$ also exhibited moderate COX-2 inhibitory activity with the $\mathrm{IC}_{50}$ values being of $2.4,7.1$ and $10.6 \mu \mathrm{M}$, respectively.

\section{EXPERIMENTAL PROCEDURE}

\section{General experimental procedures}

The NMR spectra were measured on a Bruker AC $500 \mathrm{MHz}$ NMR (Bruker, Fällanden, Switzerland) spectrometer with TMS as an internal standard. HRESIMS were recorded on a Bruker micro TOF-QII mass spectrometer (Bruker, Fällanden, Switzerland). CD spectra were measured with a Chirascan circular dichroism spectrometer (Applied Photophysics, Surrey, UK). Size exclusion chromatography was done on Sephadex LH-20 gel (GE Healthcare, Uppsala, Sweden). Column chromatography was carried out on silica gel (200-300); Qingdao Marine Chemical Factory, Qingdao, China. Single-crystal data were measured on an Oxford Gemini S Ultra diffractometer (Agilent Technologies, Santa Clara, CA, USA). Spots were detected on TLC under UV light or by heating after spraying with $12 \% \mathrm{H}_{2} \mathrm{SO}_{4}$ in $\mathrm{H}_{2} \mathrm{O}$.

\section{Fungal material}

The fungal strain SCSIO Ind09F01 was isolated from the deep-sea sediment, which was collected from the Indian Ocean (Lat: 82.04513333' N, Long: $0.497883333^{\prime} \mathrm{E}$ ) at the depth of $4530 \mathrm{~m}$ in 2013 . The isolates were stored on MB agar (malt extract $15 \mathrm{~g}$, sea salt $10 \mathrm{~g}$, agar $15 \mathrm{~g}$ ) slants at $4{ }^{\circ} \mathrm{C}$ and then deposited at CAS Key Laboratory of Tropical Marine Bio-resources and 
Ecology. The strain was identified to be a member of the Ascomycota generic on the basis of it's ITS phylogenetic analysis, and it was named as Aspergillus sp. SCSIO Ind09F01. The 528 base-pair ITS sequence (NCBI GenBank accession number KP681643) has 99\% sequence identity to that of Aspergillus sydowii strain NRRL 254 (NCBI GenBank accession number AY373869).

\section{Fermentation, extraction and isolation}

Aspergillus sp. SCSIO Ind09F01 was cultured on MB-agar plates at $25^{\circ} \mathrm{C}$ for 7 days. The seed medium consisted of malt extract: $15 \mathrm{~g}$, sea salt: $2.5 \mathrm{~g}$, distilled water: $1000 \mathrm{ml}, \mathrm{pH} 7.4-7.8$ was inoculated with strain SCSIO Ind09F01 and incubated at $25^{\circ} \mathrm{C}$ for $72 \mathrm{~h}$ on a rotating shaker ( 170 r.p.m.). Mass scale fermentation of fungal isolate SCSIO Ind09F01 was carried out using production medium of solid rice in $1000 \mathrm{ml}$ flasks (rice $200 \mathrm{~g}$, sea salt $2.5 \mathrm{~g}$, distilled water $200 \mathrm{ml}$ ) was inoculated with $10 \mathrm{ml}$ of seed solution. Flasks were incubated at $25^{\circ} \mathrm{C}$ under normal day night cycle. After 30 days, cultures from 30 flasks were harvested and subjected for organic extraction using EtOAc.

The EtOAc extracts of rice solid media of Aspergillus sp. SCSIO Ind09F01 were partitioned between petroleum ether, and $90 \%$ aqueous $\mathrm{MeOH}$, The resulting $\mathrm{MeOH}$ phase was fractionated using silica column, Sephadex LH-20, and then semi-preparative reversed-phase (SP-RP) HPLC that yielded compounds 1-12 (Figure 1).

The culture of solid rice medium was soaked in acetone and cut into small pieces and kept for 1 day. The content was filtered and evaporated under vacuum using a Buchner funnel and extracted with EtOAc until exhaustion and

Table $2{ }^{1} \mathrm{H}$ and ${ }^{13} \mathrm{C}$ NMR data for 2 and 6 (at 500 and $125 \mathrm{MHz}$, respectively, in DMSO-d6, $\delta$ p.p.m., $J$ in $\mathrm{Hz}$ )

\begin{tabular}{|c|c|c|c|c|c|}
\hline \multirow[b]{2}{*}{ Position } & \multicolumn{3}{|c|}{2} & \multicolumn{2}{|r|}{6} \\
\hline & $\delta_{c}$ & $\delta_{H}$ & $H M B C(H-C)$ & $\delta_{c}$ & $\delta_{H}$ \\
\hline 1 & $\mathrm{~N}$ & & & $\mathrm{~N}$ & \\
\hline 2 & 142.9 & & & 142.3 & \\
\hline 3 & $\mathrm{~N}$ & & & $\mathrm{~N}$ & \\
\hline 4 & 133.7 & & & 141.5 & \\
\hline 5 & 118.1 & & & 108.8 & \\
\hline 6 & 155.1 & & & 152.5 & \\
\hline 7 & N & & & N & \\
\hline 8 & 138.6 & $7.84(\mathrm{~s}, 1 \mathrm{H})$ & C-4, 5,6 & 140.3 & $8.15(\mathrm{~s}, 1 \mathrm{H})$ \\
\hline 9 & $\mathrm{~N}$ & & & $\mathrm{~N}$ & \\
\hline 10 & 29.1 & $3.54(\mathrm{~s}, 3 \mathrm{H})$ & C-2, 6 & 28.9 & $3.57(\mathrm{~s}, 3 \mathrm{H})$ \\
\hline 11 & 32.7 & $4.02(\mathrm{~s}, 1 \mathrm{H})$ & $C-4,8$ & - & - \\
\hline $1^{\prime}$ & 103.7 & $7.58(\mathrm{~s}, 1 \mathrm{H})$ & $\mathrm{C}-2,2^{\prime}$ & 103.1 & $7.38(\mathrm{~s}, 1 \mathrm{H})$ \\
\hline $2^{\prime}$ & 148.4 & & & 148.1 & \\
\hline $3^{\prime}$ & 27.6 & 2.89 (sept, 7, 1H) & $\mathrm{C}-2^{\prime}, 4^{\prime}$ & 27.6 & 2.89 (sept, 7, 1H) \\
\hline $4^{\prime}$ & 22.0 & $1.26(\mathrm{~d}, 7,3 \mathrm{H})$ & $C-2^{\prime}, 3^{\prime}, 5^{\prime}$ & 22.0 & $1.24(\mathrm{~d}, 7,3 \mathrm{H})$ \\
\hline $5^{\prime}$ & 22.0 & $1.26(\mathrm{~d}, 7,3 \mathrm{H})$ & $C-2^{\prime}, 3^{\prime}, 4^{\prime}$ & 22.0 & $1.24(\mathrm{~d}, 7,3 \mathrm{H})$ \\
\hline
\end{tabular}

Table 3 The cytotoxicity results of compounds this process was repeated thrice. The organic phase was collected and evaporated to obtain a dark brown oil crude extract ( $31.3 \mathrm{~g})$. The crude EtOAc extract was subjected to silica gel column chromatography eluted with petroleum ether/EtOAc in a gradient eluent ( $\mathrm{v} / \mathrm{v}, 50: 1,30: 1,20: 1,10: 1,5: 1$, $1: 1,0: 1$ ) to obtain eight fractions (fractions 1-8) on the basis of TLC. Fraction 3 (4.1 g) was purified by Sephadex $\mathrm{LH}-20\left(\mathrm{CHCl}_{3} / \mathrm{MeOH}, 1: 1\right)$ to afford compound 7 ( $3.0 \mathrm{~g})$. Fr. $4(400.5 \mathrm{mg})$ was purified by Sephadex LH-20 $\left(\mathrm{CHCl}_{3} / \mathrm{MeOH}, 1: 1\right)$ to give three subfractions (fr. 4.1-4.3). Fr.4.2 (110.1 mg) was further purified by SP-RP HPLC using a C18 column (YMC-Pack, ODS-A S-5 $\mu \mathrm{m} \times 12 \mathrm{~nm} 250 \times 20 \mathrm{~mm}$ i.d., $4 \mathrm{ml}$ per minute) eluting with $\mathrm{MeOH} / \mathrm{H}_{2} \mathrm{O}$ (60:40) to afford compounds $8(5.9 \mathrm{mg})$ and $11(3.7 \mathrm{mg})$. Fr. $7(3.5 \mathrm{~g})$ was subjected to ODS chromatography eluted with $\mathrm{MeOH} / \mathrm{H}_{2} \mathrm{O}$ in gradient eluent $(1: 9,2: 3,3: 2,4 ; 1,9: 1)$ to give three subfractions (fr. 7.1-7.3). Fr. $7.2(900 \mathrm{mg})$ was purified by Sephadex LH-20 (MeOH) to give four subfractions (fr. 7.2.1-7.2.4). Fr. 7.2.2 (147 mg) was further purified by SP-RP HPLC eluting with $\mathrm{CH}_{3} \mathrm{CN}-\mathrm{H}_{2} \mathrm{O}$ (50:50) to afford compounds $2(35.6 \mathrm{mg})$ and 6 $(8.9 \mathrm{mg})$. Fr. $8(4.3 \mathrm{~g})$ was subjected to silica gel column chromatography eluted with a $\mathrm{CHCl}_{3} / \mathrm{MeOH}$ in a step-wise gradient system at the ratios of 100:0, 50:1, 25:1, 10:1 and 0:100 (v/v) which yielded seven fractions. Fr. $8.2(1.3 \mathrm{~g})$ was subjected to ODS chromatography eluted with $\mathrm{MeOH} / \mathrm{H}_{2} \mathrm{O}$ (linear gradient, $50 \% \mathrm{MeOH}-100 \% \mathrm{MeOH}$ ) to give five subfractions (fr. 8.2.1-8.2.5). Fr. 8.2.3 (70.1 mg) was purified by SP-RP HPLC eluting by $\mathrm{CH}_{3} \mathrm{CN}-\mathrm{H}_{2} \mathrm{O}$ (50:50) to afford compounds $1(10.2 \mathrm{mg})$ and $\mathbf{4}(8.9 \mathrm{mg})$. Fr. 8.2.2 (4.7 mg) was purified by (SP-RP) HPLC eluting with $\mathrm{CH}_{3} \mathrm{CN}-\mathrm{H}_{2} \mathrm{O}$ (50:50) to afford compounds 3 $(3.3 \mathrm{mg})$ and $5(8.0 \mathrm{mg})$. Fr. $8.2 .5(42.1 \mathrm{mg})$ was purified by (SP-RP) HPLC eluting with $\mathrm{CH}_{3} \mathrm{CN}-\mathrm{H}_{2} \mathrm{O}$ (75:25) to afford compounds 12 (20.6 mg). Fr. 8.3 $(1.1 \mathrm{~g})$ was subjected to ODS chromatography eluted with $\mathrm{MeOH} / \mathrm{H}_{2} \mathrm{O}$ in gradient eluent (1:9, 2:3, 3:2, 4;1, 9:1) to give three subfractions (fr. 8.3.1-8.3.3). Fr. 8.3.3 (132.5 mg) was purified by (SP-RP) HPLC eluting with $\mathrm{MeOH}-\mathrm{H}_{2} \mathrm{O}$ (50:50) to afford compounds $\mathbf{9}(22.3 \mathrm{mg})$ and $\mathbf{1 0}(7.8 \mathrm{mg})$.

Sydoxanthone C (1): Yellow amorphous solid; UV (MeOH) $\lambda \max (\log \varepsilon)$ 368 (3.10), 260 (4.20), 238 (4.09), 222 (4.01) nm; FT-IR: 3361, 1626, $1022 \mathrm{~cm}^{-1} ;{ }^{1} \mathrm{H}$ and ${ }^{13} \mathrm{C}$ NMR data, see Table 1 ; HRESIMS $\mathrm{m} / \mathrm{z} 363.0521$ $[\mathrm{M}+\mathrm{H}]^{+}$(calcd for $\mathrm{C}_{17} \mathrm{H}_{14} \mathrm{O}_{7} \mathrm{~S}, 363.0533$ ).

Acremolin B (2): White amorphous solid; UV $(\mathrm{MeOH}) \lambda \max (\log \varepsilon) 257$ (4.12), 248 (4.11), 227 (4.44), 219 (4.41) nm; FT-IR: 1683, 1614, $1519 \mathrm{~cm}^{-1}$; ${ }^{1} \mathrm{H}$ and ${ }^{13} \mathrm{C}$ NMR data, see Table 2; HRESIMS $\mathrm{m} / \mathrm{z} 246.1346[\mathrm{M}+\mathrm{H}]^{+}$(calcd for $\mathrm{C}_{12} \mathrm{H}_{15} \mathrm{~N}_{5} \mathrm{O}, 246.1349$ ).

\section{Biological activities}

Cytotoxicity assay. The cytotoxic activity of compounds 1-12 was screened against the growth panel of 10 tumor cell lines of (K562, MCF-7, HeLa, DU145, U937, H1975, SGC-7901, A549, MOLT-4 and HL60) according to Bergeron et al. ${ }^{16}$

COX-2 inhibitory activity assay . COX-2, as a well-established target, is an inducible enzyme, which expression is activated by cytokines, mitogens, endotoxin and tumor promoters. The anti-inflammatory and analgesic properties of traditional Non Steroidal Anti Inflammatory Drugs (NSAIDs) are primarily due to the inhibition of COX-2. ${ }^{17}$ Hence, the compounds isolated were tested for COX-2 inhibitory activity using the COX (ovine) inhibitor

\section{Table 3 The cytotoxicity results of compounds}

Cytotoxicity $\left(I C_{50} \mu \mathrm{M}\right)$

\begin{tabular}{lcccccccccc}
\cline { 2 - 9 } Compounds & K562 & MCF-7 & Hela & DU145 & U937 & H1975 & SGC-7901 & A549 & MOLT-4 & HL60 \\
\hline 7 & NA & NA & 7.12 & 1.10 & 1.21 & NA & NA & 157 & 91.5 \\
8 & NA & NA & 1.80 & 1.51 & 0.3 & NA & 37.6 & 148 & 75.3 & 35.7 \\
11 & NA & NA & 2.22 & 1.89 & 0.288 & NA & NA & 83.7 & NA & NA \\
12 & 6.97 & 11.7 & 1.39 & 2.69 & 0.463 & 8.53 & 9.43 & 7.01 & 5.26 & 6.20 \\
TSA $^{\text {a }}$ & 0.21 & 0.04 & 0.14 & 0.08 & 0.07 & 0.04 & 0.02 & 0.04 & 0.04 & 0.04 \\
Taxol $^{\text {a }}$ & 0.003 & 0.003 & 0.012 & 0.02 & 0.005 & 0.003 & 0.003 & 0.002 & 0.003 & 0.002 \\
\hline
\end{tabular}

Abbreviation: TSA, trichostatin A.

aTSA and Taxol as a standard positive control. 
screening kit, ${ }^{18}$ according to the manufacturer's instructions. The test compounds were dissolved in DMSO and the final concentration was set as $10 \mu \mathrm{M}$. The percentage inhibition has been calculated by comparison with control incubations.

\section{CONCLUSION}

Two new compounds sydoxanthone C (1) and acremolin B (2) along with 10 known compounds (3-12) were isolated from a deep-seaderived fungi Aspergillus sp. SCSIO Ind09F01. Sydoxanthone C (1) is an analog of sydoxanthone B (3), the only difference is the methyl sulfonyl group substitution instead of methylthio group on C-2 position. Acremolin B (2) is a first analog of acremolin after its structure was revised recently. ${ }^{9}$ All the compounds were assessed for its cytotoxic ability and COX-2 inhibition efficiency. As a matter of fact among those 12 compounds, diphenyl etheric metabolites $(7,8$ and 11) showed moderate selective cytotoxicity and COX-2 inhibitory activity in the screening test. Noteworthy, $3.0 \mathrm{~g}$ of compound 7 was obtained which will make it a practical and useful starting point for combinatorial synthesize of its analog to explore further research in structure-activity relationships.

\section{CONFLICT OF INTEREST}

The authors declare no conflict of interest.

\section{ACKNOWLEDGEMENTS}

This work was supported by grants from the National Key Basic Research Program of China (973)'s Project (2011CB915503); the National High Technology Research and Development Program (863 Program, 2012AA092104), Strategic Priority Research Program of the Chinese Academy of Sciences (Grant No. XDA11030403), the National Natural Science Foundation of China (31270402, 21172230, 41476135, 41376162, 41406187, 41406187); and Guangdong Marine Economic Development and Innovation of Regional Demonstration Project (GD2012-D01-001), Guangzhou Scientific Research Project (2014J4100212).
1 Blunt, J.W., Copp, B. R., Keyzers, R. A., Munro, M. H. \& Prinsep, M. R. Marine natural products. Nat. Prod. Rep. 31, 160-258 (2014).

2 Proksch, P., Putz, A., Ortlepp, S., Kjer, J. \& Bayer, M. Bioactive natural products from marine sponges and fungal endophytes. Phytochem. Rev. 9, 475-489 (2010).

3 Rateb, M. E. \& Ebel, R. Secondary metabolites of fungi from marine habitats. Nat. Prod Rep. 28, 290-344 (2011).

4 Swathi, J., Narendra, K., Sowjanya, K. \& Satya, A. K. Marine fungal metabolites as a rich source of bioactive compounds. Afr. J. Biochem. Res. 7, 184-196 (2013).

5 Lin, X. et al. A new cytotoxic sesquiterpene quinone produced by Penicillium $\mathrm{sp}$. F00120 isolated from a deep sea sediment sample. Mar. Drugs 10, 106-115 (2012).

6 Song, X. Q. et al. Xanthone derivatives from Aspergillus sydowii, an endophytic fungus from the liverwort Scapania ciliate S. Lac and their immunosuppressive activities. Phytochem. Lett. 6, 318-321 (2013).

7 Yao, Q. et al. Cytotoxic polyketides from the deep-sea-derived fungus Engyodontium album DFFSCS021. Mar. Drugs 12, 5902-5915 (2014).

8 Hamasaki, T., Sato, Y. \& Hatsuda, Y. Structure of sydowinin A, sydowinin B, and sydowinol, metabolites from Aspergillus sydowi.. Agri. Biol. Chem. 39, 2341-2345 (1975).

9 Januar, L. A. \& Molinski, T. F. Acremolin from Acremonium strictum is N, 2, 3-Etheno2'-isopropyl-1-methylguanine, not a $1 \mathrm{H}$-Azirine. Synthesis and Structural Revision. Org. Lett. 15, 2370-2373 (2013).

10 Yurchenko, A. N. et al. A new meroterpenoid from the marine fungus Aspergillus versicolor (Vuill.) Tirab. Russ. Chem. Bull. 59, 852-856 (2010).

11 Bunyapaiboonsri, T., Yoiprommarat, S., Intereya, K. \& Kocharin, K. New diphenyl ethers from the insect pathogenic fungus Cordyceps sp. BCC 1861. Chem. Pharm. Bull. 55, 304-307 (2007).

12 Chen, M. et al. Bioactive indole alkaloids and phenyl Ether derivatives from a marinederived Aspergillus sp. fungus. J. Nat. Prod. 76, 547-553 (2013).

13 Gong, D. L. et al. Diphenyl etheric metabolites from Streptomyces sp. neau50. J. Antibiot. 64, 465-467 (2011).

14 Takenaka, Y., Hamada, N. \& Tanahashi, T. Monomeric and dimeric dibenzofurans from cultured mycobionts of Lecanora iseana. Phytochemistry 66, 665-668 (2005).

$15 \mathrm{Kim}, \mathrm{H}$. S. et al. A novel dihydroxan-thenone, AGI-B4 with inhibition of VEGF-induced endothelial cell growth. J. Antibiot. 55, 669-672 (2002).

16 Bergeron, J. J. M., Brenner, M. B., Thomas, D.Y. \& Williams, D. B. Calnexin a membrane bound chaperone of the endoplasmic reticulum. Trends Biochem. Sci. 19 124-128 (1994).

17 Praveen Rao, P. N. \& Edward, E. K. Evolution of nonsteroidal anti-inflammatory drugs (NSAIDs): Cyclooxygenase (COX) inhibition and beyond. J. Pharm. Pharmaceut. Sci 11 81-110 (2008).

18 Blobaum, A. L. et al. The 2'-Trifluoromethyl analogue of indomethacin is a potent and selective COX-2 inhibitor. ACS Med. Chem. Lett. 4, 486-490 (2013).

Supplementary Information accompanies the paper on The Journal of Antibiotics website (http://www.nature.com/ja) 